NBER WORKING PAPER SERIES

THE EFFECTS OF INFLATION AND MONEY

SUPPLY ANNOUNCEMENTS ON INTEREST RATES

Thomas Urich

Paul Wachtel

Working Paper No. 1313

NATIONAL BUREAU OF ECONOMIC RESEARCH

1050 Massachusetts Avenue

Cambridge, MA 02138

March 1984

The authors appreciate helpful comments made at a seminar at the Federal Reserve Bank of Kansas City and by William Schwert and express their thanks to Money Market Services for making the data available. The research reported here is part of the NBER's research program in Financial Markets and Monetary Economics. Any opinions expressed are those of the authors and not those of the National Bureau of Economic Research. 
NBER Working Paper \#1313

March 1984

\title{
The Effects of Inflation and Money Supply \\ Announcements on Interest Rates
}

\begin{abstract}
This paper examines the impact of the money supply and inflation rate announcements on interest rates. Survey data on expectations of the money supply and consumer and producer price indexes are used to distinguish anticipated and unanticipated components of the announcements. This distinction is used to test for the efficiency of the financial market response to the announcements of new information. The results indicate that the unanticipated components of the announced changes in the Producers Price Index and in the money supply have an immediate positive effect on short term interest rates. The Consumer Price Index announcement has no apparent effect. There is no evidence of a delayed announcement effect. However, there is some indication of a liquidity effect of the money supply change on interest rates. This takes place when reserves are changing and several weeks prior to the information announcement.
\end{abstract}

Thomas Urich Baurch College Economics Department 17 Lexington Avenue New York, NY 10010
Paul Wachtel

New York University Graduate School of Business Administration 90 Trinity Place New York, NY 10006 
The effect of money supply announcements on interest rates has attracted considerable attention in both the academic literature and the financial press in the last few years. It has been firmly established that unanticipated increases in the money supply lead to immediate increases in interest rates. However, there are several competing explanations for this phenomenon in the literature. In this paper we present some additional empirical evidence which helps to distinguish between two of these hypotheses - the polic: anticipations and inflationary expectations hypotheses - by examining the effect of money supply and inflation announcements on interest rates. The positive effect on interest rates of announcements of unanticipated changes in the money supply was demonstrated by Urich and wachtel. (1981), Grossman (1981) and Roley (1982). The announcement effect was interpreted in our earlier paper as a policy anticipations effect and has been interpreted by others, e.g. Cornell (1983a), as an inflationary expectations effect. Since both effects are in the same direction, it is difficult to distinguish between them without additional evidence. The policy anticipations effect is simply that an unanticipated increase in the money supply causes financia: market participants to expect that the Federal Reserve wili tighten the moneta:. reins in order to offset the increase. In anticipation of future tighteriso there is a tendency for interest rates to increase. The inflationary expectations effect is that an unanticipated increase in the money supply leads to an upward adjustment of inflationary expectations, which in turn leads to nigher nominal interest rates. 1 /

If interest rates respond to the money supply announcements because of inflationary expectations, then they should also be affected by the announcements of the inflation rate itself. We examine the effect of the announcements of both 
the consumer price Index and the producers price Index on interest rates. We find some evidence of inflation announcement effects, although the : are not as strong as the money supply announcement effect. Furthermore, the effect of price and money supply announcements on the Federal funds rate is examined. The overnight Federal funds rate is determined by the supply and demand for reserves over the banking week. There is little reason to expect that it will be affected by a change in inflationary expectations, while it will be affected by a change in policy anticipations. We find that the Federal Funds rate responds to the money supply announcement, but is unaffected by the inflation announcements.

An interesting aspect of our results is the comparison of the announcement effects in the periods before and after the Federal Reserve's change in operating procedures on october $\epsilon$, 1979. We find that the money supply announcement effect was much larger after october 1979. Since the Fea shifted away from interest rate targeting, the change is as expected. However, the increase in the announcement effect is so large that it suggests that additional forces are at work as well. An explanation may be found in the banking system's demand for reserves over the statement week.

The money supply announcement effect was related to reserve cemand recau of the system of lagged reserve accounting in effect until February 1984. Under that system, required reserves for the current banking week were based on deposits held two weeks ago. The end of week announcement provided data on the money supply for the previous week. Thus, the money supply announcement may have conveyed information about the aggregate demand for reserves during the current week. If the announced money supply was larger than expected, then reserve demand for the remainder of the current week could also be 
larger than expected. Interest rates increase in anticipation of tighter reserve demand for the remainder of the week. This bank reserve effect of the money supply anrouncement was not impcrtant before october 1979 because the Federal Reserve would supply whatever reserves that were necessary to maintain its Federal Funds rate target. $3 /$

A final issue explored in this paper is the relation between the announcement effect on interest rates and the traditional vien of money supply effects on interest rates. Liquidity preference theory indicates that an increase in the money supply lowers interest rates, at least as an initial effect. That is, a money supply increase is a result of an expansion of the supply of reserves through open market operations some time earlier. A negative relationship between interest rates and the subsequently announced money supply is evidence of a liquidity effect. Our data indicate that there is a liquidity effect on interest rates about three or four weeks prior to the money supply announcement.

The data are described in detail in the next section. In section 2 the announcement effect hypotheses and results are presented. Section 3 uses daily data to investigate delayed announcement effects. Finally, in Section 4 we examine the effect of changes in prices and money supply as they occur, rather than when information is announced.

\section{Data}

The effect of money supply and price index announcements on interest rates is examined for the period from November 1977 to July 1982 . In this section the data used in the study are described.

Interest rates. The source of interest rate data is the futures contracts for three-month Treasury bills traded on the International Money Market. Only the four nearest contracts are used because trading activity drops off sharply 
on longer maturity contracts. As contracts age, the time to contract maturity changes. Thus, the price of the first futures contract refers to the interest rate on three-month Treasury bills that will pertain in zero to three months. The second contract matures in 3 to 6 months and so on up to about a year. The daily settlement price is used to calculate yields on a discount rate basis. The yields used in the study, $\Delta R_{i_{t}}{ }^{\prime} i=1, \ldots, 4$, are the changes in yieiss from the previous trading day. Thus, if an information announcement takes place during the trading day, then $\Delta R_{i_{t}}$ reflects the change in interest rates from before the announcement until after the announcement. Ir the case of the mone $y$ supply announcement which takes place after the close of futures market trading, $\Delta R_{i_{t}}$ is the change in interest rates from the end of the announcement day until the next day.

An additional interest rate variable used is the Federal Funds rate. For Federal Funds, the effective rate (a transactions weighted average of trading over the day) is used. The change in the effective Fed Funds rates is denoted by $\triangle R F$. The effective rate is used because there is a great deal of intra-day variability in the Funds market. The data are taken from quote sheets prepared by Garvin Guy Butler Corporation, a major Fed Funds broker.

Information Announcements. The Consumer Price Index (CPI) and the Producer's Price Index (PPI) for the prior calendar month are announced on various days in the midale of each month. For both indexes, the measure trat is used here is the seasonally adjusted percentage change from the previous month. The series of interest are all goods for the CPI and total finished goods for the PPI. In both cases the data used are the numbers initially' announced by the Bureau of Labor Statis+ics; the PPI is subject to revision as new data become available and the seasonals for both series are revised. 
The money supply data are announced weekly. At the start of the sample period the announcement took place on Thursday afternoon, but commencing February 8, 1980 the date was switched to Friday. The information used is the weekly change in billions of dollars of the seasonally adjusted, narrowly defined money supply. At the start of the sample period this was MI. The definitions were changed in early 1980, and after that time MlB is used 4 ' The weekly change in the money supply is the difference between this week's announced level and this week's revision of the level in the previous week.

Expectations. The expectations data are from surveys conducted by Money Market Services, a San Francisco based corporation which has conducted telephone surveys since late 1977. During the week prior to each information announcement, financial market participants are asked about their expectations. For the money supply, the survey was originally conducted on Tuesday and Thursday mornings. Since the switch in the announcement day in early 1980, the survey is only conducted on Tuesday. For the CPI and PPI the surveys are conducted several days prior to the announcement. The data available to us are the survey medians. However, the mean survey data are available for the money supply expectations for part of the period. $5 /$ For the money supply, the Thursday survey responses and the means are used when available. Extensive testing showed that these were the preferred data, although the differences in results are inconsequential.

\section{Effects of Money Supply and Price Index Announcements}

In this section, we test for the effect of the announcements on interest rates. The equation used for thse tests is:

$$
\Delta R=\alpha_{0}+\alpha_{1} U+\alpha_{2} A
$$


where $A$ is the anticipation (from the survey) of the announcement and $U$ is the unanticipated component of the information announced (i.e. the actual less the anticipated). Table 1 shows estimates of this equation for all three information announcements with the sample divided in two at the time of the Federal Reserve's change in its operating procedures in October 1979. These regressions test for the presence of an immediate (one day) announcement effect, since the dependent variable is the change in interest rates from before to after the announcement.

The information announcements are decomposed into the anticipated and unanticipated components because efficient markets theory suggests that only the unanticipated component should affect rates. Thus, in an efficient marret that responds to the information announced, we expect that $\alpha_{2}=0$ and $a: \neq 0$. Both the policy anticipations and inflationary expectations hypotheses discussed earlier indicate that $\alpha_{1}$ will be positive. To repeat, the two hypotheses are:

i) An unanticipated change in the money supply leads market participants to expect that the Federal Reserve will attempt to offset the change. For example, an unanticipated increase in the money supply leads to an increase in interest rates in anticipatior of open market operations that will tighten the supply of resezves.

ii) When the announced inflation rate is larger (smaller)than anticipatec, market participants revise their inflationary evectations upward (downward). Since the expected rate of inflation is embedjed in nominal interest rates, interest rates increase (decrease).

The results shown in Table 1 provide strong support for the hypothesis that money supply announcements affect rates,but only a weak indication of any relevance of the price index announcements. In addition, the financial markets appear to be efficient with respect to these information announcements since the coefficients on the anticipated components are largely insignificant. 
The effect on interest rates of unanticipated changes in the money supply is significant in both periods. A one billion dollar unanticipated increase in the money supply leads to a 2 basis point increase in rates in the first half of the sample period and almost an 8 basis point increase in the second half. - A larger effect after the change in operating procedures is consistent with the policy anticipations effect as explained below.

There is one anomalous coefficient in the results for money supply announcements. That is, the coefficient on the anticipated component of the money supply change is significantly different from zero in the $1979-1982$ sample period. For most of this period, there are two factors that could contribute to this apparent inefficiency. First, the survey data used are medians instead of means and second, the expectations could change between the time of the survey (on Tuesday) and the announcement (on Friday). Roley (1982) suggests a procedure for correcting the survey by using the information in the change in interest rates from Tuesday to Friday. For this sample period, the adjustment reduces but does not eliminate the apparent inefficiency.

The results for the price indexes provide little indication of any announcement effects. The unanticipated component of the CPI has no affect on interest rates and the unanticipated component of tine PPI has a significant coefficient only in the second half of the sample period. This result indicates that unanticipated inflation of one per cent (per month) in the PPI leads to a 38 basis point increase in interest rates. Since the standard deviation of the unanticipated change in the PPI is .30, an unanticipated increase in the PPI of one standard deviation yields an 11.4 basis point increase in interest rates. 
Table 1

Announcement Effects on $\Delta R_{1}$

Time Period

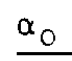

$\alpha_{1}$

$\underline{\alpha_{2}}$

$\mathrm{R}^{2}$

$\underline{N}$

Money Supply Announcement

Nov. 77-Oct. 79

$2.87(2.7)$

$2.19(3.9)$

$-1.23(1.6) \quad .143$

100

Oct. $79-\mathrm{July} 82$

$7.84(2.4)$

$7.66(5.1)$

$-7.26(2.9) \quad .178$

145

$\underline{\text { Producers Price Index Announcement }}$

Nov. 77-Oct. 79

Oct. $79-J u l y ~ 82$

Nov. 77-Oct. 79

Oct. 79-July 82

$$
-.61(.1)
$$

$5.92(.9)$

$18.97(1.2)$

$37.96(2.0)$

$2.77(.3)$

$-23.96(1.3)$

.042

.145

24

Consumer Price Index Announcement

$.59(.1)$

$-4.96(.5)$

$-.78(.1)$

.015

$4.73 \times .41$

$18.74(1.1)$

$-18.07(1.2)$

Note: Equations are of the form

$$
\Delta R_{1}=\alpha_{0}+\alpha_{1} U+\alpha_{2} A
$$

where the dependent variable is the change in interest rates from the first futures contract and $t$-statistics are in parentheses. $\mathrm{N}$ is the sample size, the number of announcements for which data are available. 
Table 2

\section{Announcement Effects on Different Interest Rates}

$\underline{\text { Time Period }}$

Nov. 77 - Oct. 79

Oct. 79 - July 82

$$
\begin{aligned}
& \Delta R F \\
& \Delta R_{1} \\
& \Delta R_{2} \\
& \Delta R_{3} \\
& \Delta R_{4} \\
& \therefore
\end{aligned}
$$

$\Delta \mathrm{R}_{1}$

$\triangle \mathrm{R}_{2}$

$\Delta \mathrm{R}_{4}$

$\underline{x_{0}}$

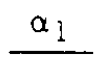

$\underline{\mathrm{R}^{2}}$

$\mathrm{N}$

\section{Money Supply Announcement}

\section{Producers Price Index Announcement}

$\begin{array}{cl}\text { Nov. } 77-\text { Oct. } 79 \quad & \Delta R \\ & \Delta R_{1} \\ & \Delta R_{2} \\ & \Delta R_{3} \\ & \Delta R_{4} \\ & \Delta R F \\ & \Delta R_{1} \\ \text { Oct. } 79-\text { July } 82 \quad & \Delta R_{2} \\ & \Delta R_{3} \\ & \Delta R_{4}\end{array}$

$1.85(2.1)$
$1.95(2.2)$
$1.06(1.2)$
$.65(.7)$
$.59(.7)$

$$
\begin{gathered}
.40(.7) \\
2.05(3.7)
\end{gathered}
$$

.006

100

$1.90(3.4)$

.120

100

$1.78(3.2)$

.104

100

$1.58(3.0)$

.094

100

.081

100

$-3.19(2.1)$

$9.67(3.7)$

.086

145

$6.25(1.9)$

$6.99(4.6)$

.131

145

$5.51(1.9)$

$6.04(4.6)$

.131

145

$4.38(1.7)$

$5.14(4.4)$

.117

145

$3.97(1.6)$

$4.72(4.2)$

.109

145

The equation estimated is of the form:

$$
\Delta R_{i}=\alpha_{0}+\alpha_{1} U \text {. }
$$

$t$ - statistics are in parentheses 
For all three announcements shown in Table 1, an F-test indicates that the null hypothesis of coefficient homogeneity across the two sample periods can not be rejected. Furthermore, the coefficients on unanticipated money or price change are not sensitive to the exclusion of the anticipated variatsles (see Table 2 for comparison). Nor do the addition of day of the week dummy variables lead to any substantive changes.

It is not surprising that the PFI announcements have a larger effect on interest rates than do the CPI announcements. The PPI announcements are generally made early in the month and the CPI announcements follow about two weeks Iater. In addition, forecasters use the PPI to forecast future movements in the CPI. Thus, the PPI announcements may convey more rew information about the overall inflationary situation. Conversations with financial market participants also indicate that more attention is paid to the PPI than to the CPI announcements. More puzzling is the difference between the inflation announcement effects in the two sample periods which may reflect differences in the inflation process. The unanticipated parts of the inflation announcements (as well as the money supply announcements) are more variable in the second half of the data which could be the cause of the increased financial market responsiveness.

Results for the announcement effects on different interest rates are shown in Table 2. These equations show the effect of unanticipated changes in the money suppiy and in the PPI on the Federal Funds rate and on yields from the first four futures contracts. There are some interesting differences among these results, particularly when the fed Funds rate (a rate on overnight loans) is comparea to the last futures contract (the 3 month bill rate expected 
in approximately a yearl.

For the money supply announcements the coefficient for the announcement effect is at least three times as large as its standard error for all the futures contracts. Prior to october 1979 there is no effect of unanticipated changes in the money supply on the fed Funds rate. This result is consistert with the then current monetary policy operating procedure. That is, the open market desk allowed little variation in the fed Funds rate and apparently took action to immediately offset any effects of the announcement. In the post-October 1979 period there is a very large effect on Fed Funds; a one billion dollar unanticipated increase in the money supply leads to almost a 10 basis point increase in the Funds rate.

The increased responsiveness to unanticipated changes ir the money suppiy follows directly from the nature of the policy change in october 1979. The Federal Reserve announced that it would allow much wider variation in the Funds rate and would concentrate open market operations on maintaining targeted growth in non-borrowed reserves and the money supply. With iess emphasis on a narrow trading range for the Federal Funcis rate, the probabilit: of a policy reaction to a money supply annnouncement is increased. While there is considerable controversy as to whether the Federal Reserve actually changed its policy orientation towards reserves and the monetary aggregates, the evidence presented here indicates that financial market participants seem to believe that there has been a change. 
The effect of unanticipated money supply changes on future interest rates depends on when the anticipated policy change is likely to take place and how long it is expected to last. In both sample periods, the effects decline as the contract maturity gets longer. The effect on $\Delta R_{4}$ is a little more than two-thirds of the effect on $\Delta R_{1}$. These results suggest that the policy responses are to some extent expected to be temporary, since there is a larger effect on bill rates expected in about three months than on bill rates expected ir about a year.

For the PFI announcements, the effects are small and weak in the early period. In the second half of the data, the coefficients are much larger and are marginally significant. The smaller t-statistics in the inflation announcement equations than in the money supply announcement available from the monthly data. In a bivariate regression the t-statistic varies directly with the sample size. There is no PPI announcement effect on the Federal Funds rate in either period. The PPI announcement effects tend to increase as we look at interest rates expected to prevail further in the future. If an unanticipated inflation announcement leads to revisions of expected inflation rates over some period of time, then an announcement effect or: future interest rates is expected.

These results do suggest that the money supply announcement effect is due to policy anticipations rather than inflationary expectations. The first reason for this is the absence of an inflation announcement effect on the shorter maturity contracts while the inflation announcement effects tend to increase with contract maturity. Since a policy response is likely to take place guickly the money supply announcement effect is likely to be a policy anticipations effect. 
Table 3

Delayed Announcement Effects

Delayed Effect

$\sum B_{j}$

$\mathrm{R}^{2}$

of :

Nov. 1977 - Oct. $1979 \quad(\mathrm{~N}=484)$

Money Supply

PPI
1.39

$-1.70$

.023

.022 .
.88

.00

Oct. $1979-$ July $1982 \quad(\mathrm{~N}=709)$

$\begin{array}{rrrr}4.55 & .058 & 2.46 & 1.85 \\ 57.48 & .051 & 1.77 & .71\end{array}$

Equation estimated is

$$
\Delta R 1_{t}=\alpha_{0}+\alpha_{1} U P_{t}+\alpha_{2} U M_{t}+\sum_{j=1}^{5} z_{j} U X_{t}-j
$$

where UX is either UP (unanticipated part of PPI announcement) or UM (unanticipated part of money supply announcement). $\mathrm{N}$ is the sample size; equations are estimated with daily data. 


\section{Table 4}

Pre-Announcement Effects

Information Variable, $\mathrm{s}^{j}$

Money Supply

$\alpha_{0}$

$\alpha$ ?

$2=$

Eo

$B_{i}$

$\mathrm{B}_{2}$

$B_{3}$

$B_{4}$

$\mathrm{R}^{2}$

F*

N
$.85(.9)$

$22.78(1.8)$

$5.99(6.7)$

$.35(.9)$

$.48(1.3)$

$-.15(.4)$

$-.80(2.2)$

$-.54(1.6)$

.0452

2. 11

1188

\section{$\underline{P P I}$}

$-.44(.3)$

$21.26(1.7)$

$5.89(6.7)$

$2.89(1.3)$

$3.35(1.5)$

$-2.83(1.2)$

$2.19(1.0)$

$.0 \div 32$

2.02

1203

The equation estimated is:

$$
\Delta R 1=\alpha_{c}+a_{1} \text { UPPI }+\alpha_{2} \text { UMS }+\sum_{j=0}^{J} \beta_{j} A^{j}
$$

Sample period is Nov. 1977 - July 1982.

* F test for the null hypothesis that all $B^{\prime}$ s are zero. 


\section{Delayed Market Responses To the Announcements}

The new information in the money supply and price index announcements is quickly and widely disseminated. Thus, the discussion in the previous section concentrates on the immediate announcement effects. However, it is possible that market responses to the new information are delayed or spread out over some period of time.

We test for the existence of delayed marke't responses by estimating regressions of the form:

$$
\Delta R_{t}=a_{0}+a_{1} u_{t}+\sum_{j=1}^{k} E_{j} U_{t-j} \text {. }
$$

In this equation $\Delta \mathrm{R}_{t}$ is a vector of daily changes in interest rates, and the vector $U_{t}$ contains the unanticipated components of announcements entered on the announcement days and zeros for non-announcement days. If the entire effect of the information announcement is immediate, then the coefficients on the lag terms should be zero. Non-zero $B_{j}$ 's indicate market responses to announcements which are delayed.

Table 3 summarizes the tests for market responses in the five trading days after the announcements. The equations include both the immediate money $s u=: y$ and PPI announcement effects and the dependent variable is the change in interest rates from the first futures contract. $?$ ' As inaicated by the F-tests it Table 3, the addition of the five lagged variables (individual coefficierts are not shown) does not increase the explanatory power of the model significantly. In addition, the sums of the lag coefficients are not significantly different from zero. Nevertheless, in the second period the sums of the lagged effects are quite large, particularly in the case of the price index. For the PPI, the effect in the five tradings days after the initial announcement impact is one art a half times as large as the initial effect. Thus, there is some indicaticn that inflationary expectations and interest rates respond gradually to an unanticipated inflation announcement. 


\section{Pre-Announcement Effect}

The information announcements provide information about economic activity which took place some time earlier. For example, a mid-month price index announcement summarizes data on prices at least a month earlier. Similarlv, the end of week money supply announcement is a report on the average money supply for the statement week ending Wednesday of the previous week. To sore extent, market participants are aware of economic phenomena as they transpire and prior to an official data announcement. A logical extension of the investigation of the announcement effects is to examine the effect of the actual money supply and price phenomena at the time that they occur.

The actual change in economic activity can occur days, if not weeks, prior to the measurement of the phenomena and the announcement of information. Thus, the following propositions regarding pre-announcement effects of new information are suggested:

i) Traditional macroeconomic theory suggests that expansion of the money supply leads to lower interest rates. Such liquidity effects are likely to occur when the money supply expands (the statement week), or even earlier when Federal Reserve open market operations expand the supply of reserves. Thus, the announcement of a money supply increase should be associated with lower interest rates some time earlier.

ii) An increase in prices will lead tc adjustments in inflationar: expectations and higher nominal interest rates when the fice increase is perceived. This can occur as the price leve? changes and prior to the announcement. Significantly positive pre-announcement effects would be evidence of such an effect.

Since these pre-announcement effects can extend over a considerable period of time, we test for their presence with variables for each week, rather than each day prior to the announcement. The equation used to test for weekly pre-announcement effects is:

$$
\Delta R_{t}=\alpha_{0}+\alpha_{1} U_{t}+\sum_{j=0}^{J} E_{j} A_{t}^{j}
$$


The $A_{t}^{j}$ variables are desiqned to represent the pre-announcement effects of the actual information. Say that there is some information announced on a particular day, then $A_{t}^{j}$ is that information for all $t$ that are in the $j$-th week prior to the particular announcement. Thus, $A_{t}^{\circ}$ is based on the announced information for days in the announcement week but before the actual announcement. Similarly, ${ }_{A}{ }_{t}$ is based on the information announced for all $t$ which are in the week prior to the announcement. The relevant information for these tests are the announced changes in the money supply and the price index.

The actual change in the money supply could affect interest rates well before the day of the announcement for several reasons. First, financial market participants gather information about the money supply prior to the announcement. Second, the information announced is for the money supply for the statement week ending 8 days prior to the announcement. Third, the money supply change is, in part, a response to changes in the availability of reserves prior to the statement week. The open market operations which determined the supply of reserves could have affected interest rates when they occured. To test for the presence of these effects, variables are entered for the week of the money supply announcement lbut prior to the announcement) ard for four leading weeks.

Several interesting conclusions can be dram from the money suppl $y$ equation in Table 4 which is estimated for the whole sample period. Ir. the week prior to the money supply announcement there is a small positive effect of money supply change on interest rates. This period corresponds approximately to the statement week. Financial market participants are likely to have some notion of the increase in the money supply taking place at that 
time and interest rates may change in anticipation of Federal Reserve policy action. If we move several weeks prior to the announcement, we find that the actual money supply change has a significant negative effect on interest rates. This effect corresponds to a liquidity effect or the standard macroeconomic result that an increase in the money supply leads to lower interest rates which takes place when open market operation affect reserves and prior to the actual change in the money supply and its subsequent announcement. The combined liquidity effect in the second to fourth week implies that a one billion doilar money supply increase reduces interest rates by about lis basis points.

For the PPI, the actual change can affect the interest rates prior to the announcement, if financial market participants perceive the price change as it occurs. That is, interest rates are affected when prices change. The PPI announced in the third week of the month refers to prices measured in the middle of the prior calendar month. The results in Table 4 indicate that there is a weak positive effect between the measurement time and the announcement, but not prior to that time. $8 /$ That is, the financial markets do not react to price change between the time it is measured and announcez. The estimated coefficients indicate that a lo morthly change in the p:? increases interest rates by about 4 i basis points over the four weeks Erio: to the announcement.

\section{Conclusion}

In the last few years the interests of macroeconomic and financial theory have begun to converge. This paper explores an area of the convergence--the effect on interest rates of information announcements. Macroeconomic theory has explored the influence of both the money supply 
and inflation on interest rates and financial theory contributes the concept of market efficiency to explain how information affects prices. The main results of the paper are:

'The unanticipated component of the announced change in the Producer's Price Index (PPI) has an immediate positive effect on short-term interest rates. The Consumer Price Index (CPI) announcerents, however, do not have any apparent effect on interest rates.

'The policy anticipations effect of the money supply announcement is much greater in the period after the Federal Reserve's announced shift in operating procedures (October 1979).

${ }^{\circ}$ Evidence of lagged announcement effects is very weak for both prices and the money supply. That is, the new information in each announcemert is rapidly incorporated in market interest rates and there is no indication of delayed impact of the information on interest rates.

oThere is some indication of a liquidity effect of the money supply on interest rates several weeks prior to the announcement. A money supply announcement is in part the consequence of changes in reserves severi? weeks earlier. At that time, there is a negative association of the subsequently measured and anxounced money supply anci interest razes. 


\section{BI BLIOGRAPHY}

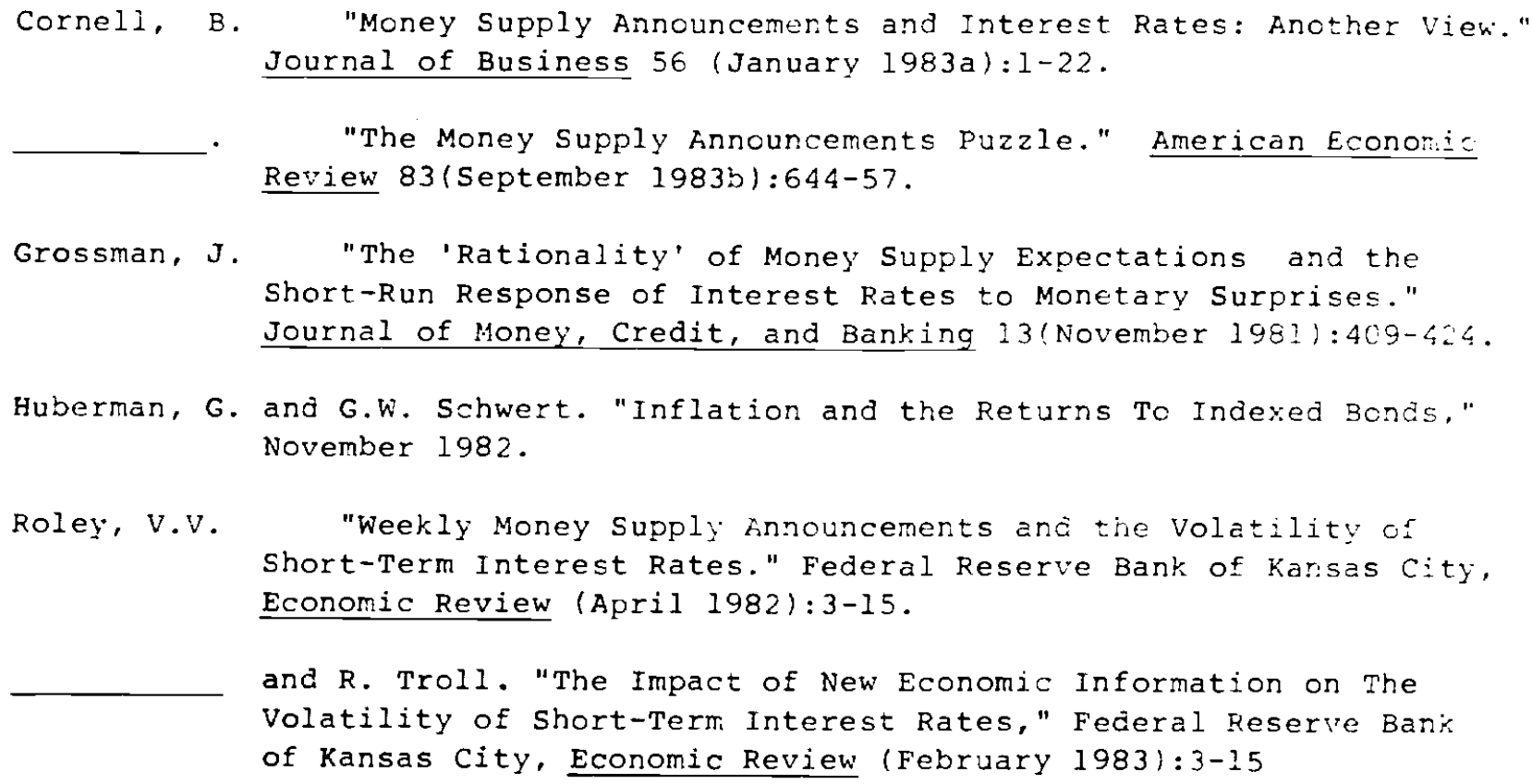

Schwert, G.W. "The Adjustment of Stock Prices to Information About Inflation." Journal of Finance 36(March 1981):15-28.

Urich, T.

"The Informational Content of Weekly Money Supply Announcements. Journal of Monetary Economics, $10\left(198^{\star 2}\right) .3-88$.

and P. Wachtel. "Market Response to the Weekly Money supply Announcements in the 1970's." Journal of Finance 36 (Decemher igzi): 1053-1072.

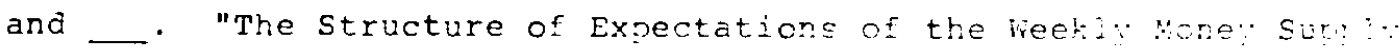
Announcement." Journal of Nonetary Economics Nazch ics.;.

Walsh, Carl. "The Effects of Alternative Operating Procedures on Econor:ic and Financial Relationships," July 1982. 
1; Urich (1982) provides a theoretical model of the policy anticipations effect and Cornell (1983b) provides a taxonomy of hypotheses concerning the mone: supply announcement. He includes the two considered here - the policy anticipations and inflationary expectations effects - and adds real activity and risk-aversion hypotheses.

2/ Schwert (1981) investigated the effect of the CPI announcement on stoch prices and found some evicience that unanticipated inflation depresses stock returns. Roley (1983) did not find any significant effects of unanticipated inflation announcements on Treasury bill yields.

3/ Walsh (1982) provides a model of the effect of the money supply announcener: on the demand for reserves and intra-week variation in interest rates.

4/ There have been changes in the announcement procedures and data definitions since the end of our sample period. In particular, the narrowly defined money supply has been revised slightly and renamed $M I$, and the announcement day returned to Thursday when the lag in reserve accounting was reduced. The examination of announcement effects was restricted to $M l$ because of the availability of expectations data (see below). Survey data on expectations of reserves, the monetary base or broader definitions of the money supply are not available.

5/ These data are analyzed in Urich and wachtel's (1984) analysis of individua: expectations.

6.' To place these responses in perspective note that the standard deviation in the unanticipated money supply change for the whole sample is aimos: s2 billion. (Urich and wachtel ig8i), and elsewhere.

I) The results are the same when the money supply and frice cmouncerents are tested separately. Filso the ccefficients on the immediate announcenert effect (the $a_{i}$ 's) which are not shown in Table 3 are virtually the same as the corresponding results in Table 2 .

8f Schwert (1981) found that the stock market reacts to the CPI arround the time of the announcement and not when the price change occurs. Huberman and Schwert (1981) find that the prices of Israeli indexed bonds respond to inflation as it occurs and prior to the announcement. We did not find any evidence of CPI effects on interest rates when the price change occurs. 